\title{
Understanding Violence in Charles Dickens' A Tale of Two Cities
}

\section{Mohammed Rasul Murad}

English Department, College of Basic Education, University of Raparin,Rania Kurdistan Region, Iraq Email:mhrasul89@uor.edu.krd

\begin{abstract}
:
This paper, Understanding Violence in Charles Dickens' A Tale of Two Cities, deals with violence in its various forms in Charles Dickens' novel, A Tale of Two Cities. The novel recounts the French Revolution of 1789. In the novel, Dickens portrays a terrifying scene of blood and brutality. Violence appears in different forms. Critics have paid attention to Charles Dickens' own fear of a similar revolution in England. The paper attempts to find the substance of that fear. The paper will discuss the three forms of violence in Dickens' A Tale of Two Cities; namely, violence as an inherent part of the French Revolution; violence committed by the crowds or mobs, and the evil that rises and grows as the Revolution continues. It will be argued that Dickens' depiction of the crowd and mob behavior in A Tale of Two Cities captures the potential which is in the mentality of any crowd to grow violent. That is, a seemingly innocent start could lead to evil. A socio-psychological approach will also be consulted to analyze violence in the novel; violence as part of the revolution; violence committed by the mobs, and finally how the revolutionary masses turn evil.
\end{abstract}

Key words: Charles Dickens, Violence, The French Revolution, A Tale of Two Cities 


\section{Introduction:}

\subsection{Fear of the French Revolution:}

Violence was one of the features of the French Revolution. "Violence, it seemed, had not been incidental to the revolution, but inherent in its popular character" (Jones, 2008, p.1). In his book-Chartism Thomas Carlyle argues that the French Revolution was not only a French event. He further argues that such a rebellion could happen anywhere. Moreover, Carlyle fears that the Chartist movement in England may turn into a violent rebellion like the French Revolution:

Or why do we ask of Chartism, Glasgow Trades-Unions, and such like?
Has not the great Europe heard the question put, and answered, on the
great scale; has not a FRENCH REVOLUTION been? Since the year 1789, there
is now half-a-century complete; and a French Revolution not yet complete!
Whosoever will look at this enormous phenomenon may find many meanings in it, but this meaning as the ground of all: That it was a revolt of the oppressed lower classes against the oppressing or neglecting upper classes: not a French revolt only; no, a European one; full of stern monition to all Europe. These Chartisms, Radicalisms, Reform Bill, Tithe Bill, and infinite other discrepancy, and acrid argument and jargon that there is yet to be, are our French Revolution: God grant that we with our better methods, may be able to transact it by argument alone! (Carlyle, 1885, p.34).

Jones (2008) states that Dickens dedicated A Tale of Two Cities to Lord John Russell, the Prime Minister of the United Kingdom from 1846 to 1852, hoping for a peaceful reformation in the government (p.17). It is, therefore, possible that Dickens echoed Carlyle's fear of a violent rebellion in England.

\subsection{Mobs:}

H. H. A. Cooper and Brooke E. Penn define a mob as "a substantial collection of individuals gathered together by accident or design for the ostensible purpose of demonstrating its inherent power" (Cooper and Penn, 2008, p.3). They argue that "a mob is a crowd gone bad" (Cooper and Penn, 2008, p 3). One could infer from this definition the distinction between a crowd, seemingly a casual gathering of individuals, and a mob, characterized by violence. A crowd, as soon as established as a group, could get bigger easily; the idea of "something going on" attracts other people to join in (Cooper and Penn, 2008, p 6). A crowd, Cooper and Penn claim, "is simply awaiting the opportunity, some catalyst that will turn it into a mob" (Cooper and Penn, 2008, p 7). How does that "turning" happen? Cooper and Penn cite Terry Pratchett, stating: "It doesn't take many people to turn a worried anxious crowd into mob. A shout here, a shove there, something thrown here... and with care, every hesitant, nervous individual is being drawn into a minority that does not, in fact, exist" (Cooper and Penn, 2008, p 1). 


\subsection{Deindividuation:}

Deindividuation as a theory, Tom Postmes and Russel Spears argue, seek to explain various acts of collective behavior, including "violent crowds, mindless hooligan and the lynch mob" (Postmes and Spears, 1998, p.238). Having referred to Gustave Le Bon's crowd theory, Postmes and Spears state, 'in the crowd, "the collective mind" takes possession of the individual, who as a consequence is reduced to an "inferior form of evolution" (Postmes and Spears, 1998, p.239). For Postmes and Spears, deindividuation "is characterized as a state of lowered (private) self-awareness and self-regulation in a group. The result of this state is antinormative behavior: acts that violate established norms of appropriateness" (Postmes and Spears, 1998, p.242).

The Old Bailey spy scene is an example of collective behavior in A Tale of Two Cities. The funeral of the supposed Roger Cly is worth considering in light of the deindividuation theory. The crowd is characterized by loud voices of every kind, such as hissing, bawling, groaning, singing, and shouting out: "Yah! Spies! Tst! Yah! Spies!" (Dickens, 2008, p.149). It is worth noting that many of the crowd members don't know what is going on in the place:

"What is it, brother? What's it about?"

"I don’t know," said the man. "Spies! Yah! Tst! Spies!"

He asked another man. "Who is it?"

"I don't know," returned the man, clapping his hands to his lips nevertheless, and vociferating in a surprising heat and with the greatest ardour, "Spies! Yaha! Tst, tst! Spi-ies!” (Dickens, 2008, p.149).

"At length," a person informs Mr. Cruncher about the matter. The crowd lacks ideas; when one of the members calls out: "Have 'em out, there! Pull 'em out, there!", Dickens says: " The idea was so acceptable in the prevalent absence of any idea, that the crowd caught it up with eagerness, and loudly repeating the suggestion to "have "em out, and pull "em out" (Dickens, 2008, p.150). As the crowd gets wild, the shops in front of its way close because "a crowd in those times stopped at nothing, and was a monster much dreaded" (Dickens, 2008, p.150). The crowds turn into a mob and become violent. As they go along the streets, new people join in and the sight becomes one of entertainment: "beer drinking, pipesmoking, song roaring" (Dickens, 2008, p.151). After the mob is done with the burial, it seeks other means of entertainment; insulting passers-by, breaking windows, sacking houses and so forth. It is possible that the members of the mob have undergone a state of deindividuation; no individual voice of protest is heard; all of them act as one bodyas a collective being. When at the beginning some of the officiating undertakers protest against the way the funeral is going to take place, other members of the crowd threaten to bring the "refractory members of the profession to reason" by immersing them in the cold river (Dickens, 2008, p.150). Thus, according to the mob, those resisting members are a threat to the being of the mob as a unified group. Accordingly, they are silenced: "the protest was faint and brief" (Dickens, 2008, p.150). Deindividuation as a theory is useful to help us understand the mentality of mob inaction; however, as the violence grows evil in the novel, it seems to have deeper roots that will be discussed later in this paper. The portrayal of the crowds as such shows two important facts; firstly, that the crowds, as noted earlier, could be dangerous and they could easily turn into a violent mob, and secondly, the wild enjoyment the mob members get from their violence is dangerous, too. This danger is more noticeable when violence dominates the later scenes of the novel. Let's now discuss the second form of violence, violence associated with the French Revolution, and see how it rises. 


\section{Violence in the French Revolution}

\subsection{The Wine Scene:}

The wine scene in front of Defarge's shop is important in two ways; on the one hand, it exposes the condition of the peasants in France, and on the other hand, it shows the potential of the oppressed classes to revenge. We will see throughout the development of events how these same ragged people turn to cruel evil. When the wine casket spills over the street of Saint Antoine, people gather to get a taste of it; the people leave "their business, or their idleness" and pour to the street. The streets are rough and irregular. This corner of Saint Antoine is inhabited by desperate people; people who are grinded by "the mill that grinds young people old" (Dickens, 2008, p.23). Dickens remarks that "hunger was prevalent everywhere (Dickens, 2008, p.32). Besides, the place is darkened with "cold, dirt, sickness, ignorance,..." (Dickens, 2008, p.32). Such is the life of the peasants of Saint Antoine and perhaps all over France. This wine spilling scene shows another side of the poor; that is, their capability to stand up and revenge. A tall joker among the crowd scrawls "with his finger dipped in muddy wine-lees-Blood" on the wall (Dickens, 2008, p.32). The narrator comments that a time will come when blood will split over these same streets. These people do not have food, but they do have "tools and weapons"; sharp and bright knives and axes; heavy hammers and murderous gun stocks (Dickens, 2008, p.33). The narrator predicts a time when:

For, the time was to come, when the gaunt scarecrows of that region should have watched the lamplighter, in their idleness and hunger, so long, as to conceive the idea of improving on this method, and hauling up men by those ropes and pulleys, to flare upon the darkness of their condition (Dickens, 2008, p.33-4).

\subsection{The Oppressor and the Oppressed:}

The cause of the people's hunger is the mistreatment and neglect of the ruling classes. For example, Monsieur the Marquis's carriage steps over a child and kills him in Saint Antoine. The narration seems to suggest that the Marquis was one example of the behavior of the ruling classes' treatment of the poor, there were other carriages which also wounded or killed people and even left them behind: "carriages were often known to drive on, and leave their wounded behind" (Dickens, 2008, p.105). Monsieur the Marquis looks on those people as dogs that he could kill any time he wishes; he threatens them: "I would ride over any of you very willingly and exterminate you from the earth" (Dickens, 2008, p.107). This extent of oppression comes from the Marquis's idea that "it must all go his way-tend to his own power and pocket...", and that "the world was made for them" (Dickens, 2008, p.101). In his last encounter with Charles Darnay, Marquis says, "Repression is the only lasting philosophy. The dark deference of fear and slavery...will keep dogs obedient to the whip" (Dickens, 2008, p.117).

The passages above picture a conflict between the neglecting ruling classes and the neglected starving peasants. Monseigneur has a lavish lifestyle: "Monseigneur was out at a little supper most nights, with fascinating company" (Dickens, 2008, p.100). The peasants, on the contrary, are desperate in want and hunger; they are perhaps "fed and freed" only when they are fast asleep, "dreaming of banquets, as the starved usually do, and of ease and rest, as the driven slave 
and the yoked ox may,..."(Dickens, 2008, p.121). With this remarkable gap between the two classes, violent rebellion is perhaps the only choice left for the poor.

\subsection{Armed in Hunger and Revenge:}

The time comes; the people of Saint Antoine, "all armed alike in hunger and revenge," rise and stand up to the injustice:

The hour was come, when Saint Antoine was to execute his horrible idea of hoisting up men for lamps to show what he could be and do. Saint Antoine's blood was up, and the blood of tyranny and domination by the iron hand was down- down on the steps of the Hôtel de Ville where the governor's body lay-down on the sole of the shoe of Madame Defarge where she had trodden on the body to steady it for mutilation (Dickens, 2008, p.211).

The peasants find Foulon alive after he had feigned death. In a satirical manner, Dickens shows how ridiculous the revolutionaries could be in their treatment with the regime. As it will be further discussed later, Dickens' story witnesses noth the breakdown of the old regime and the moral breakdown of the one to come. Foulon was the man who told the starving people to eat grass if they did not have bread; they killed him and filled his mouth with grass in revenge (Dickens, 2008, p.216). People of the country, too, rebel and set the château on fire. The destruction of the old regime being done, the age of the Monseigneur as a class is brought to an end. The ruling classes, Dickens states, "had, somehow or other, brought things to this" (Dickens, 2008, p.218). Dickens reiterates this idea in other places in his novel, for example, when a Monseigneur at Tellson's Bank in London speaks slightingly about the revolutionaries and vows to avenge himself on them, Dickens comments:

It was too much the way of Monseigneur under his reverses as a refugee, and it was too much the way of native British orthodoxy, to talk of this terrible Revolution as if it were the one only harvest ever known under the skies that had not been sown- as if nothing had ever been done, or omitted to be done, that had led to it- as if observers of the wretched millions in France, and of thee misused and perverted resources that should have made them prosperous, had not seen it inevitably coming, years before, and had not in plain words recorded what they saw (Dickens, 2008, p.228. emphasis added).

What Dickens shows here is that those people are oppressed by a cruel regime. As a result, the people stand up to the injustice and begin violence to get rid of the old regime and bring a new one. The fact that the ruling class has brought things to this makes it possible to say that the violence, too, as part of the Revolution is blamed on that class. Nevertheless, this does not mean that Dickens' Tale condones violence committed by the peasants in revenge. In the events to follow (after the triumph of the Revolution) Dickens exposes the dark side of those same poor people; they grow violent; they shed blood of innocent people, even peasants, and they get a beastly pleasure from it. It is important to notice how violence grows in the French Revolution. 


\subsection{The Growing Violence:}

As shown above, violence seems to be an inevitable part of the Revolution. The Revolution had a seemingly innocent start; innocent here implies that at least it was not intended to be evil. Given the plight and the unjust suffering of the peasants at the hands of the Marquis and the likes of him, one would imagine that the Revolution came about as a force, though a violent one, to bring back justice to the society. Thus, for example, when one of the Jaqueses killed the Marquis, he might have been applauded for doing an act of justice. But what happens to the Jacqueses? How they, or at least Jacques Three, grow to be so cruel and inhumane to wish there were more kids to be guillotined? The same question applies to the other revolutionary populace who started by killing tyrant people like Marquis and Foulon, but grew to condemn peasants and put innocent people to the merciless Guillotine. Recalling the violence of the mob in the funeral of Roger Cly, what would have happened if the mob was not ended by the news that the guards were coming, is pretty much what is happening in France. That is to say, once the old regime is toppled and the revolutionaries come to power, there is no order besides their own, and there is no law besides their "self-appointed" tribunes. In other words, they tend to do what they want to without any check and kill whoever they think or "suspect" to be an enemy of the Republic. Crowd violence should not be confused with state repression. Nevertheless, who can tell which is what as the Revolution grows violent? Ernest Defarge, Dr. Manette finds, is one of the judges in the tribune (Dickens, 2008, p.260); The Vengeance can defy the judge's bell for silence (Dickens, 2008, p.304), and Jaques Three is not only a member of the jury but has their votes (Dickens, 2008, p.345).

The violent acts turn into extremes and Dickens portrays it as self-destructive. This self-destructive nature of violence plays out well in the violent deaths of Madame Defarge and Sidney Carton. At the beginning of the novel, Madame Defarge is presented as a rather passive character, spending most of her time knitting. Knitting, however, is symbolic of scheming. As such, part of her time is spent writing people's names in her imaginary list of the ones to be killed. Given that she has a disturbing past with the Evremonde brothers, she believes that she has every right to pursue her bloody plans. As the revolution triumphs, the novel tracks the violent acts of Madame Defarge. What is particularly interesting is her own violent death when in a confrontation with Miss Pross she fires the gun and the bullet turns towards her. Dickens shows that Madame Defarge's lust for vengeance, as was the case with many other characters, was ultimately self-damaging.

Sidney Carton's violent tendencies and excessive acts represents a desire for freedom from what he calls a wasted life (Kucich, 1980). His death shows the fulfillment of his redemption on a personal level.

In the violent deaths of the above characters, Dickens points to the self-destructive power of violence, suggesting that extreme violence results in the demise of the characters and possibly the revolution by large. 


\section{A Psychological Analysis of Violence:}

\subsection{Evil:}

Roy F. Baumeister argues that, "Large-scale evil is probably most often the end of a long road that no one foresaw at the start" (Baumeister, 1999, p.282). The French Revolution in fact, as noted above, did not start as cruel as we see it at the end. The killings first include the visible and obvious enemies of the people. As the events unfold, however, those enemies increase; maybe the definition of enemy is broadened rather. The victims will later include a peasant who is accused of plotting against the Republic. The dreadful deeds that followed were not imagined by the revolutionaries themselves; Dickens states, "The frightful deeds that were to be soon done, were probably unimagined at that time in the brains of the doers" (Baumeister , 1999, p.244). This is when Charles Darnay is being arrested; at that time, it seems, things had not gone very nasty. Not very late after, however, Darnay will learn, and we will learn how violence gets bloodier each day.

The mob that gathers in the courtyard behind Tellson's bank in Paris is a sight of blood and horror, "Such awful workers and such awful work!" (Dickens, 2008, p.251), Mr. Lorry notices. We learn that they are sharpening their knives and other weapons to kill the prisoners. "The eye could not detect one creature in the group free form the smear of blood" (Dickens, 2008, p.252). In that same night when Mr. Lorry is at Tellson's, the mob comes back two other times to the sharpening-stone. The time is marked by such ambience of blood, filth and cruelty by the crowds who murder the prisoners. Here again one can see this potential of the crowds to get inhuman when there is no censure.

\subsection{Desensitization:}

The paper has pointed to the fact that violence in the Revolution grows over time; what contributes to that growth is important. One of the factors that help worsen an already violent condition, Baumeister argues is "desensitization." "Desensitization", Baumeister defines, "is essentially a matter of getting accustomed to something and ceasing to react strongly to it" (Baumeister , 1999, p.285). This desensitization, not being upset at all by murdering people, is clearly obvious in the Marquis. When his carriage kills the child in Saint Antoine, he, rather than feeling remorse, gets angry at the crowd and blames them for not caring for their own lives. The revolutionary crowds, however, who initially rebelled against people like the Marquis, get as violent as he was, if not worse. Madame Defarge develops "absolutely without pity" (Dickens, 2008, p.347); the mender of roads, now the wood sawyer, gets accustomed to going to the Guillotine and smoking his pipe while heads are being cut (Dickens, 2008, p.346). These are on personal levels nevertheless. The crowds, the way Dr. Mannette describes, are doing similar acts. Lucy learns later that within four nights "eleven hundred defenceless [sic] prisoners of both sexes and all ages had been killed by the populace" (Dickens, 2008, p.259). And this happens every day as killing the prisoners becomes very much something of a routine. 


\subsection{For the Fun of It:}

Another factor that contributes to escalation of violence is "discovering the pleasure" (Baumeister ,1999, p.293). Baumeister argues that "the discovery that hurting people can be a direct source of pleasure" makes people do more violence to get more of the enjoyment (Baumeister ,1999, p.293). In A Tale of Two Cities, the victory of the Revolution itself is a source of pleasure, and that is not the problem. The danger lies in the fact that those revolutionary crowds commit more acts of violence, and once they find out that they enjoy the dreadful deeds, they naturally tend to get more of that pleasure. In the sharpening-stone scene one could see that the mob gets a "beastly excitement" from the nasty act. The mender of roads gets a foolish pleasure from the saw he calls Little Guillotine. He imagines the billets heads of men, women and children (Dickens, 2008, p.266). The revolutionary tribunes get to thousands and they are established in all towns and cities. Moreover, the law of the Suspected "struck away all security for liberty or life, and delivered over any good and innocent person to any bad and guilty one; prisons gorged with people who had committed no offence, and could obtain no hearing" (Dickens, 2008, p.262). La Guillotine, Dickens ironically says, had become a source of pleasure:

It was the popular theme of jests; it was the best cure of headache, it infallibly prevented the hair from turning grey, it imparted a peculiar delicacy to the complexion, it was the National Razor which shaved close (Dickens, 2008, p.262).

But it actually provided pleasure and pastime for many people who gathered to see blood splash from it. Jacques Three gets a sadistic pleasure when he imagines seeing Little Lucy on the Guillotine: “"The child also," observed Jacques Three, with meditative enjoyment of his words, "has golden hair and blue eyes. And we seldom have a child there. It is a pretty sight"' (Dickens, 2008, p.344). Enjoyment is visible in many acts of violence in the novel. In the Old Bailey spy scene violence is accompanied by sport and entertainment; they did it with smoking, drinking and singing (Dickens, 2008, p.151). A wilder mob walks through the streets of Paris for a certain celebration of the Revolution, and passes by Lucy. They beastly dance about the streets "like five thousand demons;" Dickens remarks that no fight could be uglier and more violent than their dance (Dickens, 2008, p.266). The festival is apparently rejoicing the triumph of their terrible violence as the houses are adorned with red colour and spikes. Baumeister argues that getting pleasure from hurting others itself is not the initial cause of violence, but once the pleasure is discovered, it serves as additional cause: "Henceforth, their [violent people's] violent acts spring from the original cause and the additional motive of enjoyment" (Baumeister ,1999, p.294).

\subsection{Ambiguity:}

Baumeister believes that ambiguity in the rules a group sets against its enemies is another factor contributing to mounting violence (Baumeister ,1999, p.294). He thinks that "evil is in the eye of the beholder"; meaning that violent acts are scarcely recognized as evil by the perpetrators. Once an ambiguous law imposes violence, the act "may seem cruel or violent form one perspective but correct and even morally obligatory from another" (Baumeister ,1999, p.295). This implies a broadening of the definition of enemy, as observed earlier. According to the new laws of the revolutionary tribunes, for instance, it is not easy to determine whether Lucy and her child are "enemies of people," and they therefore should be punished for, not Charles Darnay's, but his father and uncle's crimes against people. Thus, when the SelfAppointed Tribune condemns Darnay in the second trial for being an enemy of the people and the Republic, it would probably be in vain to say to the tribune that Darnay himself detested that family name and left France because of it. The 
ambiguous accusations of "plotting", "enemy of people" and "enemy of the Republic" do a great deal of violence. They send many innocent people to La Guillotine. A poor farmer like the seamstress whom Sydney Carton sees in the condemnation day shows how dangerous those laws could be. In addition, Dickens reports that vague suspects imprisoned or guillotined many innocent people:

The air around was so thick and fitful, the people were so passionately revengeful and fitful, the innocent were so constantly put to death on vague suspicion and black malice, it was so impossible to forget that many as blameless as her [Lucy's] husband and as dear to others as he was to her, every day shared the fate from which he had been clutched...(Dickens, 2008, p.278).

\subsection{Diffusion of Responsibility:}

Diffusion of responsibility, in the instance of group violence, could be another reason why violence escalates, Baumeister argues; "The larger the group, the less responsible any individual person feels" (Baumeister, 1999, p.299). Accountability in the legal sense is even less likely to take place in the post-revolution arena as the old regime is gone, and with it all laws for punishment. The idea of revolution seems to suggest bringing about a new system and destroying the old regime in probably many aspects of the political and social structure, including the legal system. Thus, one can argue, the fact that there is no law to punish the violent revolutionaries makes it meaningless for an individual to feel responsible for doing what the larger group does, even if what they are doing is morally questionable.

The fact that "groups suppress private doubts," could make a violent group more effective as a team, and this way violence escalates (Baumeister, 1999, p.303). Baumeister believes that it happens when an individual in a group has doubts about the actions of the group. Nevertheless, these personal doubts are often ineffective and the group acts its way, because the individuals do not express their doubts (Baumeister, 1999, p.303). In the mob that gathers on Roger Cly's funeral, some of the officiating undertakers did express their objection to the way the proceedings for the funeral were going to take place; however, one could argue that those were not part of the mob, and even if they were, their objection was soon suppressed. When Ernest Defarge objects to killing Dr. Manette, his wife thinks him weak, and Jacques Three seems to doubt whether he is a good citizen (Dickens, 2008, p.344). His objection is weak, too; he does not object to the horrible deeds his wife and others have been doing and are going to continue to do on strong moral grounds; he is for "extinction in general," but only not for Dr. Manette (Dickens, 2008, p.325). In a group, Bauseimer argues, individuals with doubts will "feel ashamed of these doubts" (Baumeister, 1999, p.304). Baumeister refers to the French Revolution as an example. He argues that much of the cruelty rose as a result of private doubts being suppressed by the mob. As such, the fear of being accused of being weak, or not faithful enough for the revolution, made the individual doubts stay private (Baumeister, 1999, p.304). 


\section{Conclusion:}

In conclusion, this paper has traced the roots of violence in Charles Dickens' A Tale of Two Cities. The paper has attempted to point to the three forms of violence in the novel. Violence as part of the Revolution is inevitable; any act of revolution will inherently include violence, and violence in fact might be necessary for the revolution to take place in the first place. The French Revolution, as pictured in the novel, was initially an outcry against tyranny and injustice. The second form of violence is that of mobs; we found that in a mob there is a different mentality at play. That is, the individuals in a mob could undergo a state of deindividuation that could make the individuals do what they would not do had they not been under that state. Violence in the third form seemed more subtle and apparently more evil than the other two forms. This was called evil in this paper. Guided by Bausteimers theory that evil or violence grow over time, the paper found out that evil violence in the novel, at the hands of the revolutionaries specifically, was influenced by different factors. Those factors helped it develop into its most severe extent towards the end of the novel. It was argued that when A Tale of Two Cities was written, there was yet fear of violence in England; citing from Thomas Carlyle's Chartism, it was found that the fear was genuine because once the crowds start violence, it might pass through bloody events similar to that of France. The paper also drew attention to the possibility that Dickens himself might have feared such bloody violence to haunt his country. Once violence starts, Dickens' Tale shows, it could escalate and get bloodier over time. The violence that came about with a seemingly innocent intention, to do an act of justice, turned into some demonic acts of bloodshed and sadism that probably no one could foresee in the beginning.

\section{References:}

Baumeister, F. (1999) Evil: Inside Human Violence and Cruelty. W.H. Freeman and Company Ltd, New York.

Carlyle, T. (1885). Chartism. John B. Alden, New York.

Cooper, A. and Brooke E. Penn. (2008). "Crowds and Violence: Negotiating with Mobs." Journal of Police Crisis

Negotiations. 9.1. Pp. 3-33. Web. 18 September. 2019.

Dickens, Charles. (2008). A Tale of Two Cities. Oxford World's Classics. Ed. Andrew Sanders. Oxford University Press, New York.

Jones, S. (2008). "The Redemptive Power of Violence? Carlyle, Marx and Dickens." History Workshop Journal. 65.1.Pp. 1-22. Web. 20 June 2019.

Kucich, J. (1980). The Purity of Violence: “A Tale of Two Cities.” Dickens Studies Annual, 8, pp.119-137. 
Postmes, T. and Spears, R. (1998). "Deindividuation and Antinormative Behavior: A Meta-Analysis."Psychology Bulletin. 123.3. Pp. 238-259. Web. 10 August 2019.

\section{بوخته:}

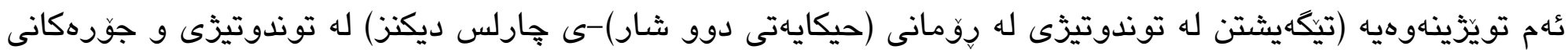

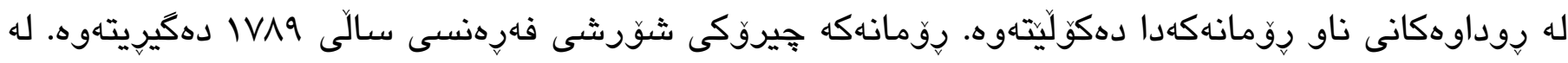

روّمانهكها، جارلس ديكنز ديمهنى زوق توندوتيز و ترسناكى شوّرشهكه وينا دهكات. توندوتيزّى به شيّوهى جياواز له روّمانه كها دهردهكهويت. بوّيه رهخنهكران سهرنجى ئهوهيان داوه كه رهنكَه ئهو وينّاكردنه ترسناكه رِنكدانهوهى ترسى

ديكنز بيت له روودانى رووداويَكى هاوشيّوه له شانشينى يهكرتوو. ئه تويَّينهوهيه له سلى جوّى توندوتيزّى له

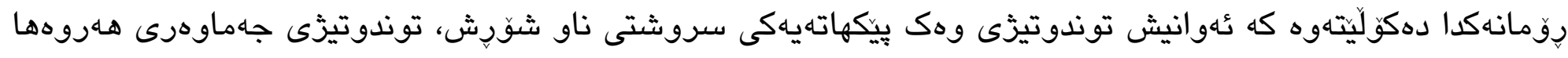

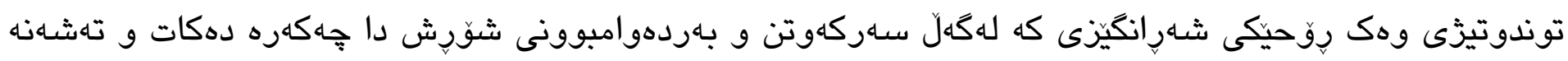

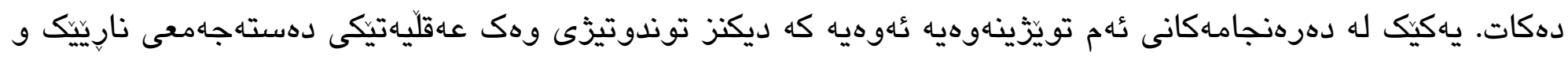
خوّرسك يِيشان دهدات. هـروهها، ديكنز توندوتيزّى وهك حالهتيك بِيشان دهدات كه ئهَّرى دروستبوون و

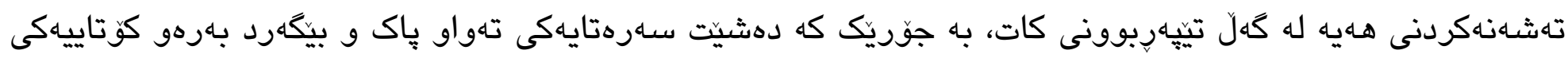

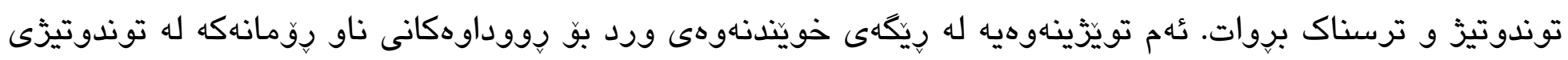

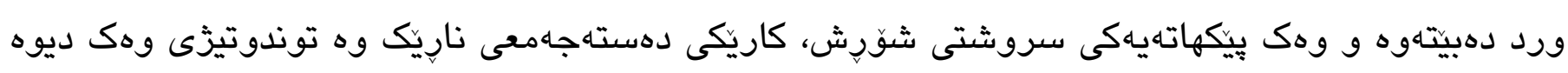

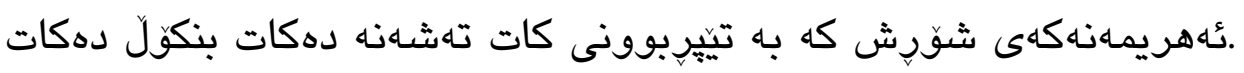

